\title{
Characterization Sodium Carboxymethyl Cellulose from Alpha Cellulose Betung Bamboo (Dendrocalamus asper)
}

\author{
Herman Suryadi*, Sutriyo, Ghina Fauziah
}

\section{Herman Suryadi*, Sutriyo, Ghina Fauziah}

Faculty of Pharmacy, Universitas Indonesia Depok, INDONESIA.

\section{Correspondence \\ Herman Suryadi \\ Faculty of Pharmacy, Universitas Indonesia, Depok, INDONESIA. \\ Email: hsuryadi@farmasi.ui.ac.id \\ History \\ - Submission Date: 08-02-2019; \\ - Review completed: 12-04-2019; \\ - Accepted Date: 24-05-2019.}

DOI : 10.5530/pj.2019.11.143

Article Available online

http://www.phcogj.com/v11/i5

\section{Copyright}

(C) 2019 Phcogj.Com. This is an openaccess article distributed under the terms of the Creative Commons Attribution 4.0 International license.

\begin{abstract}
Objective: Sodium carboxymethylcellulose $(\mathrm{Na}-\mathrm{CMC})$ is one of pharmaceutical excipients that can be used to increase viscosity in topical, oral and parenteral pharmaceutical formulation, beside that it can also be used as binder and disintegrant in tablet formulation. Betung bamboo is one of natural material that contains high concentration of holocellulose for about $83.80 \%$. The purpose of this study was to characterize Na-CMC obtained through alkalization and carboxymethylation reaction. Methods: Alkalization was carried out using $25 \%$ sodium hydroxide and $1.7 \%$ sodium tetraborate. Carboxymethylation was done with sodium monochloroacetate to alpha cellulose ratio $1.3: 1$. Product was identified by FTIR and further characterized by XRD, SEM, DS value and $\mathrm{pH}$. Result: The product was white colour powder which has similarities of its infrared spectrum to reference. Other characteristics that showed similarities to reference was degree of substitution $0.7073, \mathrm{pH} 7.61$, average of particle size distribution $71.54 \mu \mathrm{m}$, moisture content $5.88 \%$, sulfated ash content $32.64 \%$ and loss on drying $9.85 \%$. Conclusion: Based on the comparison of X-ray diffraction, there is similarity between reference and product ( $\mathrm{Na}-\mathrm{CMC}$ ) from betung bamboo. However, there were differences in melting temperature, viscosity and morphological analysis with SEM to reference.
\end{abstract}

Key words: Betung bamboo, Cellulose, Sodium carboxymethylcellulose, Alkalization, Carboxymethylation, Characterization.

\section{INTRODUCTION}

Sodium carboxymethyl cellulose is used in oral and topical dosage formulations in pharmaceutical field. Sodium carboxymethyl cellulose can also be used as binder and disintegrant in tablet formulation, increase viscosity and emulsifying agent. ${ }^{1}$

In Indonesia, sodium carboxymethyl cellulose that used in pharmaceutical industry is imported from another country, it can cause drug prices rise. Whereas, Indonesia has many natural sources of cellulose that can be used to produce sodium carboxymethyl cellulose.

Cellulose is the basic structure of plant cells that made by living organisms. The most common source of cellulose in the pharmaceutical field is wood which has cellulose content of $40-50 \%{ }^{2}$ However, the use of wood as source of cellulose is considered less effective because wood is often used as household raw material and has long growing time, therefore it is necessary to find another source of cellulose that has short growing time. Bamboo has very short growing time. Bamboo can be harvested within 4 years after planting, it is shorter than wood that can be harvested in $8-20$ years. ${ }^{3}$

Betung bamboo (Dendrocalamus asper) contains $83.80 \%$ holocellulose, $30.20 \%$ lignin, $4.63 \%$ ash, $3.51 \%$ silica and extractive substances. ${ }^{3}$ Cellulose of betung bamboo can be obtained from extraction with organic solvent and isolation with alkaline solution that produces alpha cellulose. Alpha cellulose that obtained is used as a material for produces sodium carboxymethyl cellulose. Sodium carboxymethyl cellulose is synthesized through two stages, alkalization and carboxymethylation. Alkalization was carried out using sodium hydroxide that produces more reactive alkaline cellulose. Whereas in carboxymethylation, sodium monochloroacetate is used to produces sodium carboxymethyl cellulose.

Previous research that conducted by Koh (2013) showed that $25 \%$ sodium hydroxide produces sodium carboxymethyl cellulose with the highest degree of substitution $(0,6047) .{ }^{4}$ But, in this research the pharmaceutical degree of substition $(0,7-1,2)$ was not fulfilled, therefore it is necessary to modify the method for preparing pharmaceutical sodium carboxymethyl cellulose.

In this study, alpha cellulose will be obtained from isolation process and after that it will be used to produce sodium carboxymethyl cellulose. Furthermore, identification and characterization will be performed by comparing the product with sodium carboxymethyl standard.

\section{MATERIALS AND METHODS}

\section{Materials}

Betung bamboo powder that is used in this study was obtained from Balai Penelitian Tanaman Rempah dan Obat (Balitro), Bogor.

\section{Tools and instruments}

The tools and instruments used in this study were infrared spectrophotometry (FTIR-8400S Shimadzu, Japan), Differential Scanning Calorimetry 
(PerkinElmer, USA), analytical balance (Sartorius, Germany), Bulk density tester (BDT M4-005/04, Indonesia), $\mathrm{pH}$ meter (Eutech, Singapore), furnace (Cole-Parmer, USA), Hot plate and stirrer (IKA Tipe Hs-7, Germany), Particle Size Analyzer (CILAS 1190, France), Scanning Electron Microscope (QUANTA 650, USA), X-Ray Diffractogram (XRD Panalytical X'Pert Pro MPDb, Europe), Moisture Content (ADAM AMB50, USA), Viscometer (Cole-Parmer, USA), sintered funnel (Pyrex, Germany), filter paper (Whattman, Germany), aluminium foil (Total Wrap, Indonesia), crucible (RRC, China), oven (Heraeus, Germany), desiccator (Duran, Germany), burette (Pyrex, Germany) and other glass wares commonly used in laboratories.

\section{Chemicals}

Chemicals used in this study were n-hexane (Merck, Germany), ethanol 96\% (Merck, Germany), nitric acid (Merck, Germany), sodium hydroxide (Merck, Germany), sodium sulfite (Merck, Germany), sodium nitrite (Merck, Germany), sodium hypochlorite (Merck, Germany), sodium monochloroacetate (Merck, Germany), sodium tetraborate (Merck, Germany), isopropyl alcohol (Merck, Germany), potassium bromide (Merck, Germany), glacial acetic acid (Merck, Germany), methanol (Merck, Germany), sulfuric acid (Merck, Germany), hydrochloric acid (Merck, Germany), methyl red (Merck, Germany), phenolphthalein (Merck, Germany), alpha naphthol (Merck, Germany), anhydrous sodium carbonate (Merck, Germany), potassium biphthalate (Merck, Germany), aquadestilata (Brataco, Indonesia) and sodium carboxymethyl cellulose standard (Merck, Germany) as reference.

\section{METHODS}

\section{Extraction of Betung bamboo powder}

The extraction process was done using the method of Kharismi. ${ }^{5}$ Before the extraction, betung bamboo (Dendrocalamus asper) powder was washed using water and was dried in $60^{\circ} \mathrm{C}$ oven for about $8 \mathrm{~h}$. The extarction process was carried out using maceration method with $2 \mathrm{~L}$ of n-hexane-ethanol $(2: 1)$ as solvent for about $24 \mathrm{~h}$. The residue from filtering process was dried in room temperature for $24 \mathrm{~h}$.

\section{Isolation of Alpha cellulose from betung bamboo}

The isolation of alpha cellulose from betung bamboo method of Suryadi, Sutriyo, Sari and Rosikhoh was used. ${ }^{6}$ A 200 g of betung bamboo powder was mixed in $2.67 \mathrm{~L} 3.5 \%$ nitric acid (contain $26.7 \mathrm{mg}$ sodium nitrite). The mixture was heated on hotplate at $90^{\circ} \mathrm{C}$ for $2 \mathrm{~h}$. After that the mixture was filtered and the residue was washed with aquadestilata. It was digested with $2 \mathrm{~L}$ solution containing $2 \% \mathrm{w} / \mathrm{v}$ each of sodium hydoxide and sodium sulfite at temperature of $50^{\circ} \mathrm{C}$ for 1 h. Again, it was washed, filtered and bleached with $1.34 \mathrm{~L} \mathrm{1:1}$ aqueous dilution of $3.5 \% \mathrm{w} / \mathrm{v}$ sodium hypochlorite at boiling temperature for $10 \mathrm{~min}$. The washed and filtered material was next treated with 1.33 L $17.5 \% \mathrm{w} / \mathrm{v}$ sodium hydoxide at $80^{\circ} \mathrm{C}$ for $30 \mathrm{~min}$. The resulting alpha cellulose was washed thoroughly with aquadestilata and filtered. The product was dried in $60^{\circ} \mathrm{C}$ oven for about $3 \mathrm{~h}$.

\section{Preparation of sodium carboxymethyl cellulose}

The method of Koh with slight modification was used. ${ }^{4}$ First of all, $20 \mathrm{~g}$ of cellulose powder from betung bamboo was weight and added to $600 \mathrm{~mL}$ isopropyl alcohol with continuous stirring. Then, $67 \mathrm{~mL}$ of $25 \%$ sodium hydroxide (contain $1,7 \%$ sodium tetraborate) was added dropwise into the mixture and further stirred for an $\mathrm{h}$ at room temperature. The carboxymethylation was started when $26 \mathrm{~g}$ of sodium monochloroacetate was added with continuous stirring for another 1.5 $\mathrm{h}$. The mixture was covered with aluminium foil and placed on hotplate at $55^{\circ} \mathrm{C}$ for $3 \mathrm{~h}$. The slurry was subsequently soaked in $225 \mathrm{~mL}$ methanol. It was neutralized with glacial acetic acid to $\mathrm{pH} 7$ and than filtered using sintered funnel. The final product was washed for three times by soaking in ethanol $80 \%$ for $10 \mathrm{~min}$ and than it was washed again with methanol for the last time. The obtained sodium carboxymethyl cellulose from betung bamboo was filtered and dried at $55^{\circ} \mathrm{C}$.

\section{Identification and characterization}

\section{Infrared spectrum}

Infrared spectra of sodium carboxymethyl cellulose was recorded with FTIR-8400S Shimadzu. Pellets was made by using $\pm 1 \mathrm{mg}$ sample and $\pm 99 \mathrm{mg}$ potassium bromide. Transmission was measured at the wavelength number range of $4000-400 \mathrm{~cm}^{-1}$.

\section{$X$-Ray diffraction (XRD)}

XRD analysis was performed to see the crystalline and amorphous form of sodium carboxymethyl cellulose. Sodium carboxymethyl cellulose was analyzed using X-Ray Diffractogram Panalytical X'Pert Pro MPDb.

\section{Scanning Electron Microscopy (SEM)}

The morphological structure of sodium carboxymethyl cellulose was analyzed using QUANTA 650 Scanning Electron Microscope.

\section{Organoleptic examination}

The characteristics of product (shape, color, taste and smell) was compared with sodium carboxymethyl cellulose standard.

\section{Qualitative analysis}

$1 \mathrm{~g}$ of sodium carboxymethyl cellulose was added in $50 \mathrm{~mL}$ aquadestilata and stirred until the mixture homogeneous. $1 \mathrm{~mL}$ of solution was taken and mixed with $1 \mathrm{~mL}$ aquadestilata, after that 5 drop of alpha naphthol was added and than $2 \mathrm{~mL}$ sulfuric acid was added slowly. The reaction shows positive result when purple color is formed.?

\section{Melting temperature}

$10 \mathrm{mg}$ of carboxymethyl cellulose was weighted and analyzed using PerkinElmer Differential Scanning Calorimetry using heat from $40^{\circ} \mathrm{C}$ to $900^{\circ} \mathrm{C}$ with heat flow $20^{\circ} \mathrm{C} / \mathrm{min}$.

\section{Degree of substitution}

$1 \mathrm{~g}$ of dry sodium carboxymethyl cellulose was stirred in $20 \mathrm{~mL}$ ethanol $96 \%$ for $5 \mathrm{~min}$. Than $5 \mathrm{~mL}$ of $2 \mathrm{M}$ nitric acid was added, after that the mixture was boiled. The solution was removed from the hotplate and further stirred for $10 \mathrm{~min}$. The mixture was separated into two parts, which was solid and liquid phase. The liquid phase was removed and the solid phase was washed with $10 \mathrm{~mL}$ of $80 \%$ ethanol at $60^{\circ} \mathrm{C}$ for 5 times. Lastly, the precipitate was dried at $100^{\circ} \mathrm{C}$ for $3 \mathrm{~h}$.

The product was weighed and inserted to $250 \mathrm{~mL}$ erlenmeyer, $100 \mathrm{~mL}$ of aquadestilata was added and stirred. Then $25 \mathrm{~mL}$ of $0.3 \mathrm{M}$ sodium hydroxide was added and heated to boil for $15 \mathrm{~min}$. After the product dissolved, the mixture was titrated with $0.3 \mathrm{M}$ hydrochloric acid. Phenolphtalein was added to observe the color change from dark pink to colorless. The titration was repeated twice and the average volume of hydrochloric acid used was recorded. ${ }^{4}$

$$
\begin{aligned}
& \% \mathrm{CM}=\frac{[(\mathrm{Vo}-\mathrm{Vn})] \mathrm{M} \times 0,059 \times 100}{\mathrm{~m}} \\
& \mathrm{DS}=\frac{162 \times \% \mathrm{CM}}{\lceil 5900-(58 \times \% \mathrm{CM})\rceil}
\end{aligned}
$$

Where:

$\mathrm{Vo}=\mathrm{mL}$ of hydrochloric acid used to titrate blank,

$\mathrm{Vn}=\mathrm{mL}$ of hydrochloric acid used to titrate samples,

$\mathrm{M}=$ molar concentration of hydrochloric acid used, 
$\mathrm{M}=$ sample amount $(\mathrm{g})$

$162 \mathrm{~g} / \mathrm{mol}$ is the molar mass of the anhydroglucopyranose unit (AGU) and $59 \mathrm{~g} / \mathrm{mol}$ is the molar mass of $-\mathrm{CH}_{2} \mathrm{COOH}$

\section{Degree of acidity $(\mathrm{pH})$}

$1 \mathrm{~g}$ of sodium carboxymethyl cellulose was added in $100 \mathrm{~mL}$ aquadestilata and heated at $70^{\circ} \mathrm{C}$ until it dissolved. Degree of acidity of solution was measured by Eutech $\mathrm{pH}$ meter. ${ }^{8}$

\section{Analysis of particle size and particle size distribution}

$0.1 \mathrm{~g}$ of sodium carboxymethyl cellulose was weighted and dissolved in $10 \mathrm{~mL}$ destilled water. It was analyzed using CILAS 1190 particle size analyzer.

\section{Water content analysis}

$1 \mathrm{~g}$ of sodium carboxymethyl cellilose was weighted and analyzed using ADAM AMB50 moisture content analyzer.

\section{Sulfated ash content analysis}

First of all, the crucible was burned in $600^{\circ} \mathrm{C}$ furnance for $30 \mathrm{~min}$ and cooled in desiccator, after that the crucible was weighed until constant weight. $1 \mathrm{~g}$ of sodium carboxymethyl cellulose was added to the crucible. The crucible was burned and cooled in desiccator for $30 \mathrm{~min}$. After that, the residue was moistened with $1 \mathrm{~mL}$ aquadestilata and $1 \mathrm{~mL}$ sulfuric acid. The mixture was heated gently until white fumes were no longer evolved and ignited in the furnance until all black particles disappear. The crucible was cooled in desiccator, few drop of aquadestilatasulfuric acid (1:1) was added and again heated. The ignition was carried as before, cooled and then weighed. This was repeated until the sample reached a constant weight. ${ }^{9}$

\section{Loss on drying}

$1 \mathrm{~g}$ of sodium carboxymethyl cellulose was weighed and placed into crucible. It was dried in oven at $105^{\circ} \mathrm{C}$ until the sample reached a constant weight. ${ }^{9}$

\section{Particle density}

Bulk density and tapped density of sodium carboxymethyl cellulose was measured using BDT M4-005/04 bulk density tester.

\section{Viscosity}

$1 \mathrm{~g}$ of sodium carboxymethyl cellulose was weighed and dissolved in $100 \mathrm{~mL}$ aquadestilata. The viscosity of solution was measured using Cole-Parmer Viscometer.

\section{RESULT AND DISCUSSION}

\section{Isolation of alpha cellulose from betung bamboo}

The isolation of alpha cellulose divided into three main processes. First is the delignification. It was done using 3.5\% nitric acid and the mixture of $2 \%$ sodium hydroxide $-2 \%$ sodium sulfite (1:1). Second, bleaching process using $10 \%$ sodium hydroxide - water (1:1) and the last was dehemicellulose using $17.5 \%$ sodium hydroxide. The use of $17.5 \%$ $\mathrm{NaOH}$ was intended to separate alpha cellulose fraction (insoluble) from the soluble fraction (beta and gamma), ${ }^{2}$ this process was done to obtain alpha cellulose that can be used to produce carboxymethyl cellulose (Table 1).

\section{Preparation of sodium carboxymethyl cellulose}

Preparation of sodium carboxymethyl cellulose is divided into two processes, alkalization and carboxymethylation. Alkalization was carried out using $25 \%$ sodium hydroxide and $1.7 \%$ sodium tetraborate with isopropyl alcohol as reaction medium. $\mathrm{NaOH}$ is used for convert cellulose to alkali cellulose which is more reactive. Alkali brings about the swelling of native cellulose fiber, which cause modifications of crystallinity of cellulose structure and increased the accessibility of carboxymethyl group to cellulose structure. ${ }^{10}$ Sodium tetraborate was added to increase the quality of solution, which can also increase the degree of substitution of the product. ${ }^{11}$ Carboxymethylation was done with sodium monochloroacetate to alpha cellulose ratio 1.3:1. Furthermore, the suspension was neutralized with glacial acetic acid to $\mathrm{pH}$ 7. After that the suspension was washed using $80 \%$ ethanol and methanol to eliminate the other impurities. ${ }^{4}$

From Table 2, the yield of $\mathrm{Na}-\mathrm{CMC}$ is approximately ranging from $95.36 \%$ until $108.76 \%$. The reason as why the yield can larger than the raw material it self (cellulose) is due to the addition of monochloroacetic acid during carboxymethylation. ${ }^{12}$

\section{Table 1: Yield of cellulose from betung bamboo.}

\begin{tabular}{ccc} 
Mass of betung bamboo & Mass of alpha cellulose & Yield of alpha cellulose \\
\hline 200.77 gram & 58.30 gram & $29.04 \%$ \\
200.27 gram & 53.90 gram & $26.91 \%$ \\
\hline
\end{tabular}

Table 2: Yield of sodium carboxymethyl cellulose from alpha cellulose betung bamboo.

\begin{tabular}{ccc} 
Mass of cellulose & $\begin{array}{c}\text { Mass of sodium } \\
\text { carboxymethyl cellulose } \\
\text { (Na-CMC) }\end{array}$ & Yield of Na-CMC \\
\hline 20.0081 grams & 19.0805 grams & $95.36 \%$ \\
20.0175 grams & 19.7198 grams & $98.51 \%$ \\
20.0080 grams & 21.7605 grams & $108.76 \%$ \\
\hline
\end{tabular}

Table 3: Wavenumber of functional groups of avicel pH 101 and alpha cellulose from betung bamboo.

\begin{tabular}{ccc} 
& \multicolumn{2}{c}{ Wavenumber $\left(\mathrm{cm}^{-1}\right)$} \\
Functional groups & Avicel $\mathrm{pH} 101$ & $\begin{array}{c}\text { Alpha cellulose } \\
\text { betung bamboo }\end{array}$ \\
\cline { 2 - 3 } $\mathrm{OH}$ & 3338 & 3325 \\
$\mathrm{CH}$ stretching & 2899 & 2895 \\
$\mathrm{CH}_{2}$ & 1429 & 1421 \\
$\mathrm{C}-\mathrm{O}-\mathrm{C}$ glycosidic & 1155 & 1153 \\
$\mathrm{C}-\mathrm{OH}$ & 1047 & 1060 \\
\hline
\end{tabular}




\section{Identification and characterization}

Functional groups that showed in infrared spectra of alpha cellulose consists of $\mathrm{OH}$ group at wavenumber $3650-3200 \mathrm{~cm}^{-1}, \mathrm{CH}$ stetching at $3000-2850 \mathrm{~cm}^{-1}, \mathrm{CH}_{2}$ at $1465 \mathrm{~cm}^{-1}, \mathrm{C}-\mathrm{OH}$ bond at $1000-1260 \mathrm{~cm}^{-1}$ and C-O-C glycosidic at $1200-980 \mathrm{~cm}^{-1}$ (Figure 1 and Table 3). ${ }^{13-15}$

Carboxyl groups and its salt show two peaks at the wavenumber about $1600-1640 \mathrm{~cm}^{-1}$ and $1400-1450 \mathrm{~cm}^{-1}$ which indicates the presence of carboxymethyl substituent. The band around $1421-1425 \mathrm{~cm}^{-1}$ and $1325 \mathrm{~cm}^{-1}$ are assignedto $\mathrm{CH}_{2}$ scissoring and $\mathrm{OH}$ bending vibration (Figure 2 and Table 4$).{ }^{15}$

XRD analysis was conducted to see the shape of the crystal sample compared to reference, Na-CMC standard. The X-ray diffractogram of crystalline polymers produce sharp peak, while the amorphous polymers tend to produce a widened or blund peak. ${ }^{6}$ Diffractogram of $\mathrm{Na}-\mathrm{CMC}$ from alpha cellulose betung bamboo showed the similarity with diffractogram reference. In Na-CMC standard there is a typical pattern of diffractogram, on $2 \theta$ value of 19.985 contained a sharp peak that shows the nature of the crystalline and on $2 \theta$ value of 36.8801 the blunt and widened peak or valley shows amorphous nature (Figure 3a). While $\mathrm{Na}-\mathrm{CMC}$ from alpha cellulose betung bamboo indicated $2 \theta$ value of 19.7343 contained a sharp peak and on $2 \theta$ value of 35.4429 contained the blunt and widened peak (Figure $3 \mathrm{~b}$ ).
Analysis with scanning electron microscope showed Na-CMC standard and $\mathrm{Na}-\mathrm{CMC}$ from alpha cellulose from betung bamboo have different morphological structure. The standard has long-shape with relatively smooth surface (Figure 4), however Na-CMC from alpha cellulose betung bamboo has round-shape with relatively rough surface (Figure 5). This difference can occur due to the use of alpha cellulose (raw materials) from different sources (Table 5). ${ }^{16}$

The characterization processes of $\mathrm{Na}-\mathrm{CMC}$ from alpha cellulose betung bamboo which was compared with reference showed the similarity. However, the melting temperature of the product was higher than reference, it showed that there were still impurities in the product. Particle density of the product and the reference also showed the differences, the product has higher particle density because the mass of the product is heavier than standard reference. Moreover the viscosity of the product and the reference showed a huge difference, the product could be categorized as medium viscosity $\mathrm{Na}-\mathrm{CMC}$, while the reference was as medium viscosity grade $\mathrm{Na}-\mathrm{CMC}$. That can occur due to the use of alpha cellulose from different sources. ${ }^{17}$

\section{CONCLUSION}

The product showed similarity of the characteristics to the reference on infrared spectra, XRD diffractogram, organoleptic analysis, qualitative

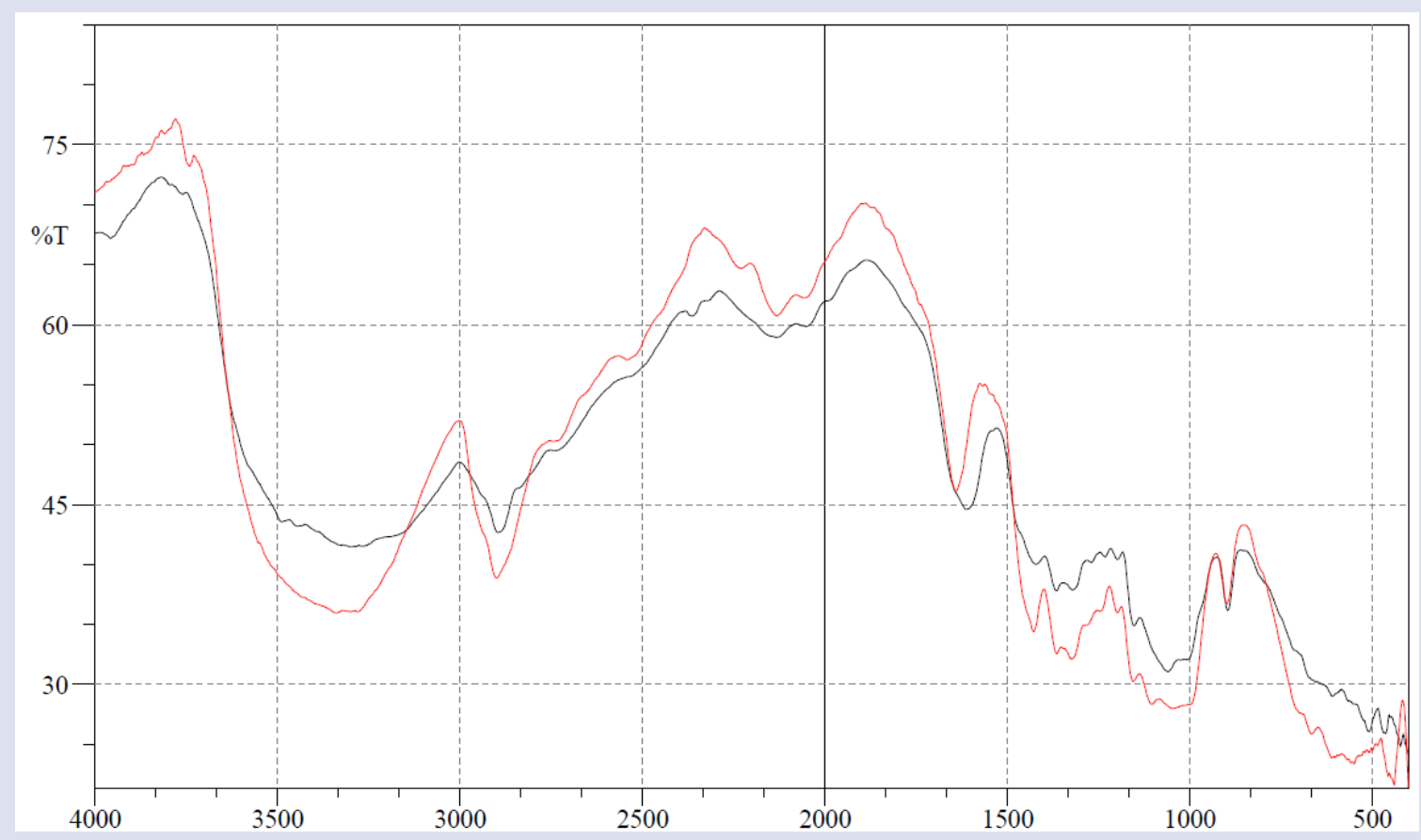

Figure 1: Infrared spectrum of avicel pH 101 (red) and alpha cellulose from betung bamboo (black).

Table 4: Wavenumber of functional groups of $\mathrm{Na}-\mathrm{CMC}$ standard and $\mathrm{Na}-\mathrm{CMC}$ from alpha cellulose betung bamboo.

\begin{tabular}{ccc} 
Functional groups & \multicolumn{2}{c}{ Wavenumber $\left(\mathrm{cm}^{-1}\right)$} \\
Na-CMC standard & $\begin{array}{c}\text { Na-CMC from alpha } \\
\text { cellulose } \\
\text { betung bamboo }\end{array}$ \\
\hline $\mathrm{OH}$ & 3607 & 3618 \\
$\mathrm{CH}$ stretching & 2877 & 2879 \\
$\mathrm{C}=\mathrm{O}$ carboxyl & 1678 & 1678 \\
$\mathrm{CH}_{2}$ & 1431 & 1421 \\
$\mathrm{OH}$ binding vibration & 1325 & 1325 \\
$\mathrm{C}-\mathrm{O}-\mathrm{C}$ glycosidic & 1153 & 1126 \\
$\mathrm{C}-\mathrm{OH}$ & 1064 & 1020 \\
\hline
\end{tabular}




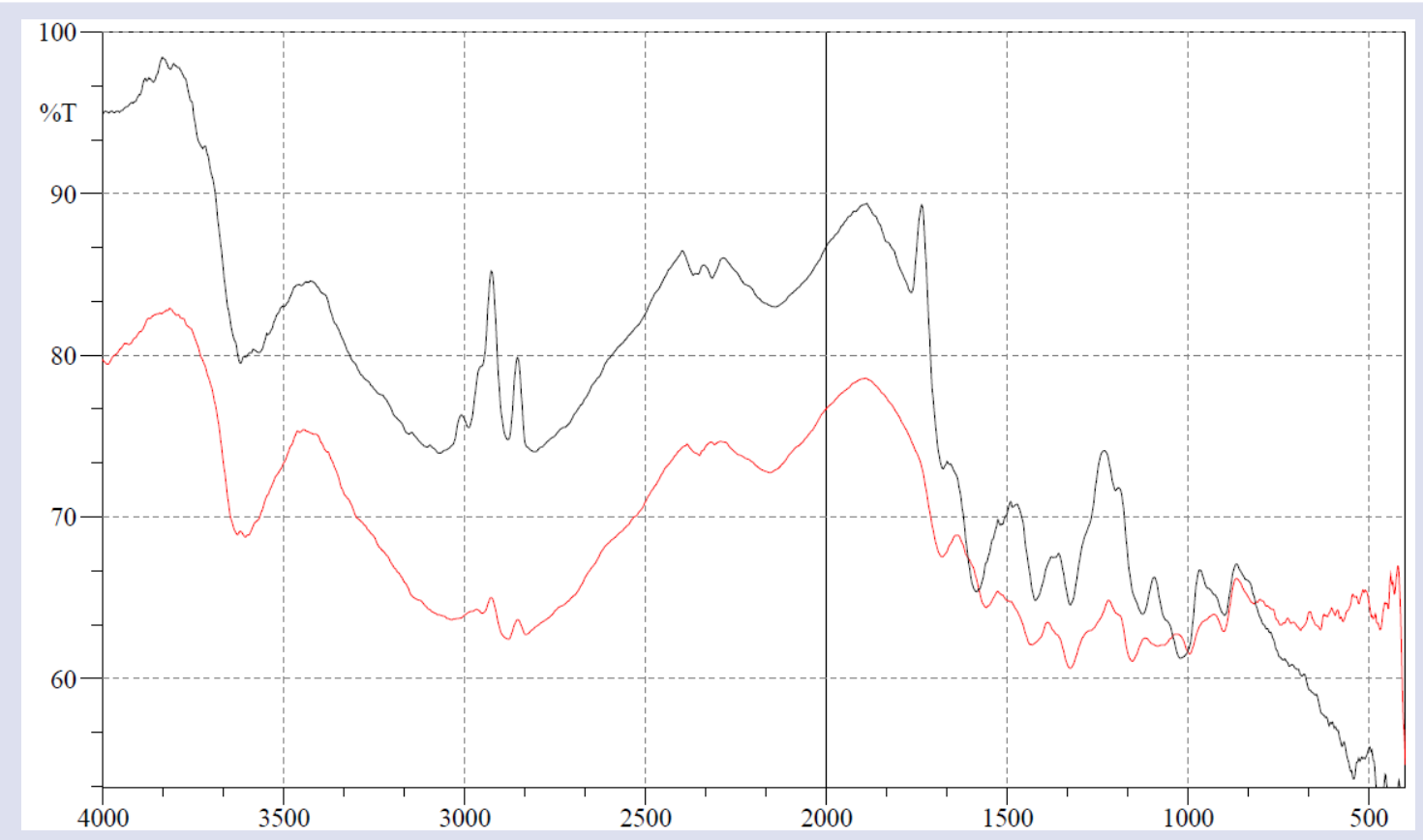

Figure 2: Infrared spectrum of Na-CMC standard (red) and Na-CMC from alpha cellulose betung bamboo (black).
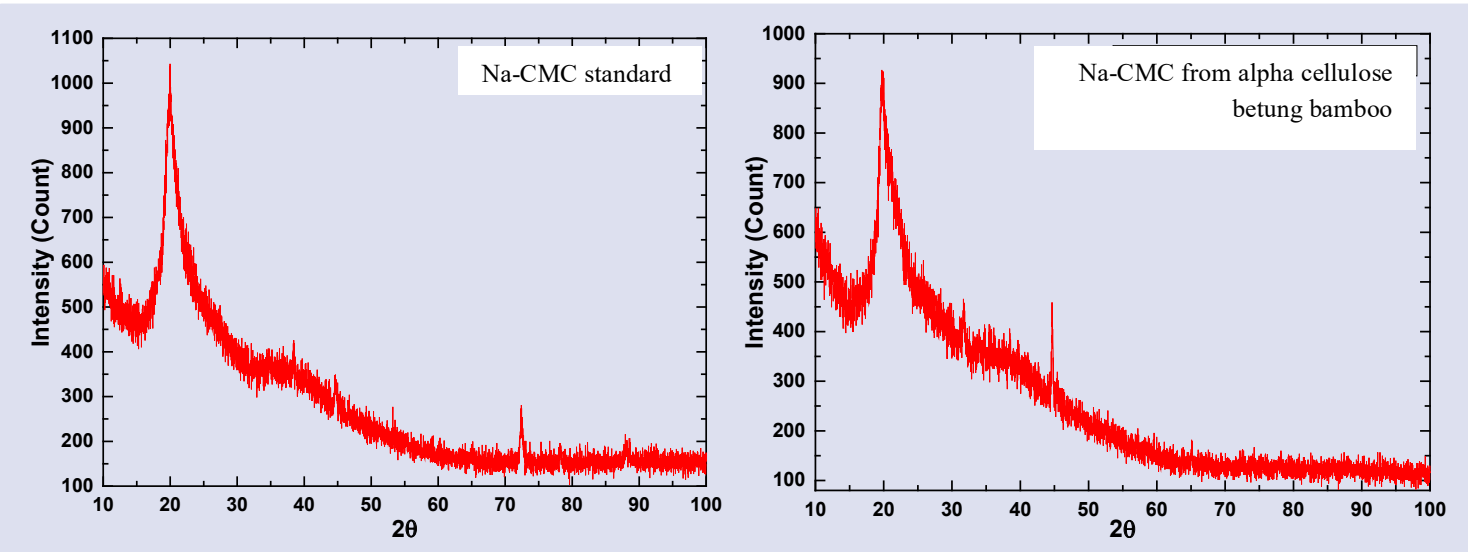

Figure 3: X-ray diffractogram of $\mathrm{Na}-\mathrm{CMC}$ standard and $\mathrm{Na}-\mathrm{CMC}$ from alpha cellulose betung bamboo.

Table 5: The result of characterization $\mathrm{Na}-\mathrm{CMC}$ from alpha cellulose betung bamboo compared with $\mathrm{Na}-\mathrm{CMC}$ standard.

\begin{tabular}{|c|c|c|}
\hline Characterization & $\mathrm{Na}-\mathrm{CMC}$ standard & $\begin{array}{l}\text { Na-CMC from alpha cellulose } \\
\text { betung bamboo }\end{array}$ \\
\hline Organoleptic & White powder, odorless and tasteless & White powder, odorless and tasteless \\
\hline Qualitative analysis & $\begin{array}{c}\text { Positive } \\
\text { (purple color was formed) }\end{array}$ & $\begin{array}{c}\text { Positive } \\
\text { (purple color was formed) }\end{array}$ \\
\hline Melting temperature & $230.10^{\circ} \mathrm{C}$ & $255.30^{\circ} \mathrm{C}$ \\
\hline Degree of substitution & 0.7433 & 0.7073 \\
\hline Degree of acidity $(\mathrm{pH})$ & 6.93 & 7.61 \\
\hline Average of particle size distribution & $55.13 \mu \mathrm{m}$ & $71.54 \mu \mathrm{m}$ \\
\hline Water content & $9.86 \%$ & $5.88 \%$ \\
\hline Sulfated ash content & $31.29 \%$ & $32.64 \%$ \\
\hline Loss on drying & $10.17 \%$ & $9.85 \%$ \\
\hline \multicolumn{3}{|l|}{ Particle density } \\
\hline Bulk density & $0.33 \mathrm{~g} / \mathrm{cm}^{3}$ & $0.42 \mathrm{~g} / \mathrm{cm}^{3}$ \\
\hline Tapped density & $0.50 \mathrm{~g} / \mathrm{cm}^{3}$ & $0.64 \mathrm{~g} / \mathrm{cm}^{3}$ \\
\hline Viscosity & $3527.7 \mathrm{Cp}$ & $20.8 \mathrm{Cp}$ \\
\hline
\end{tabular}




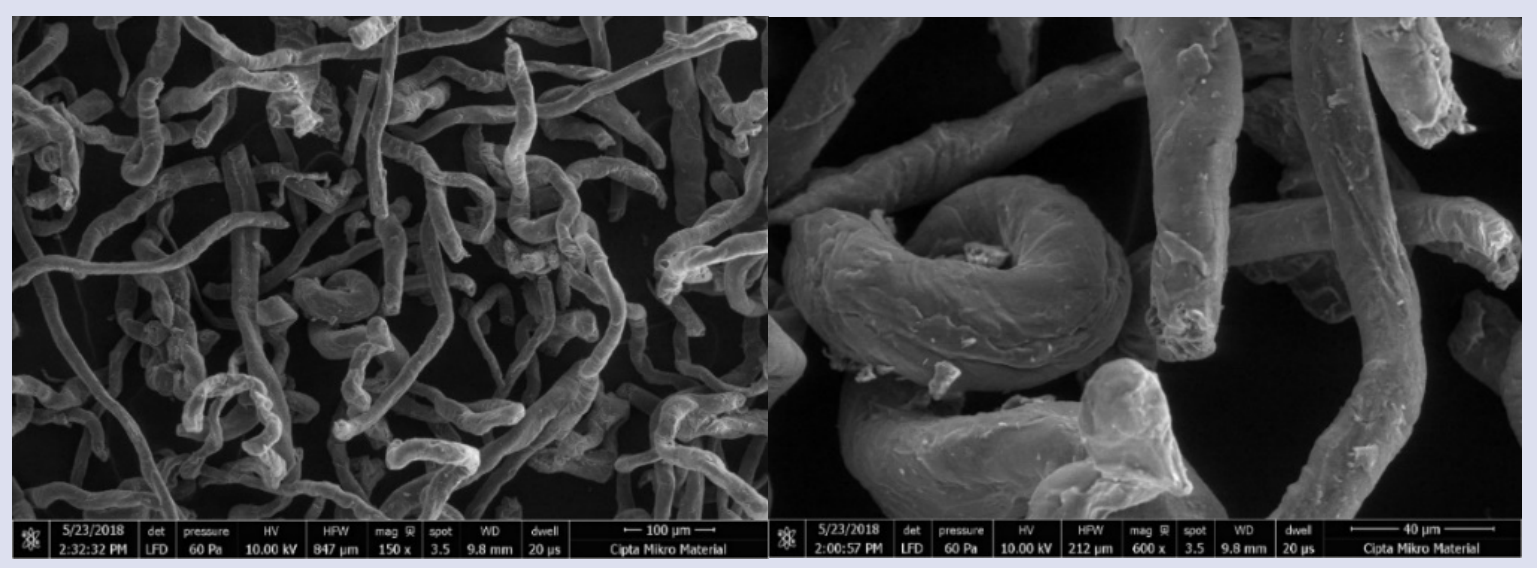

Figure 4: The result of SEM Na-CMC standard.

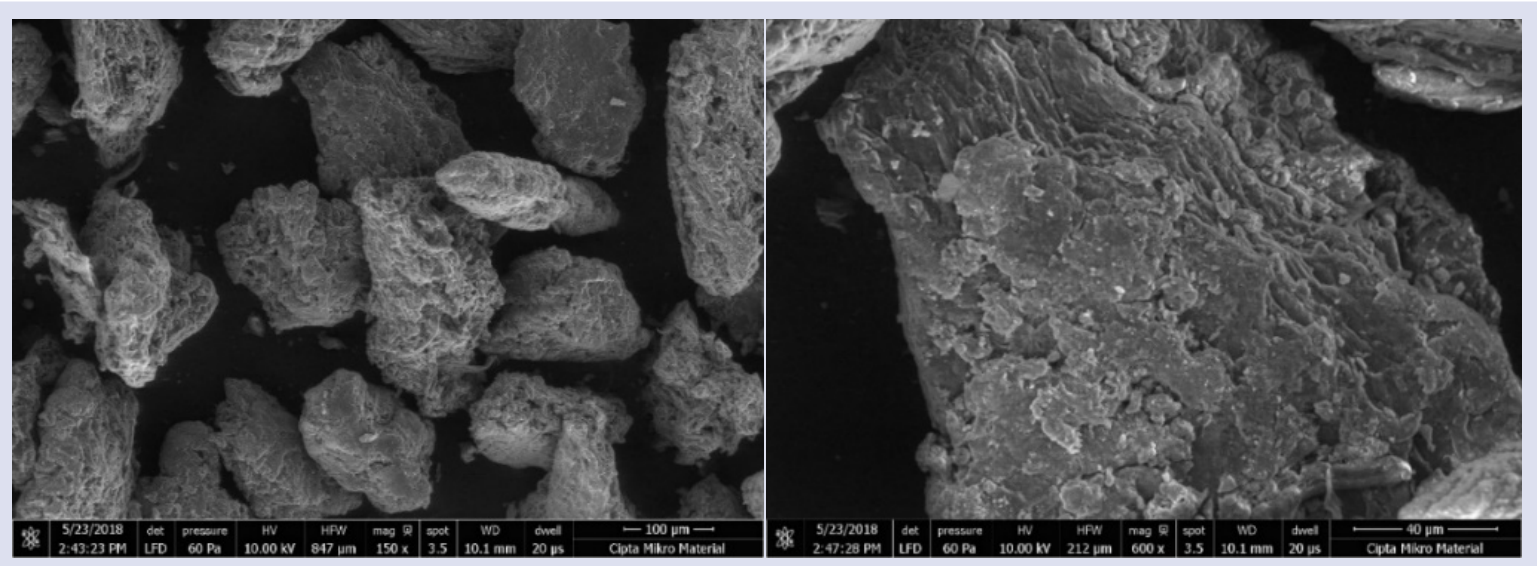

Figure 5: The result of SEM Na-CMC from alpha cellulose betung bamboo.

analysis, degree of substitution, degree of acidity $(\mathrm{pH})$, average of particle size distribution, water content, sulfated ash content and loss on drying. However, there were differences in melting temperature, viscosity and morphological analysis with SEM to reference.

\section{SUGGESTION}

It is necessary to do the optimization of the alpha cellulose isolation process which produce higher yield of alpha cellulose. Beside that, it is also necessary to reasearch the degree of polimerization and molecular weight to show the correlation with the viscosity of the product.

\section{ACKNOWLEDGEMENT}

This study was supported by Hibah Publikasi Internasional Terindeks Untuk Tugas Akhir Mahasiswa UI (PITTA) 2018 by Universitas Indonesia. We thank PITTA 2018 for providing the fund that used in the study.

\section{REFERENCES}

1. Rowe RC, Sheskey PJ, Quinn ME. Handbook of Pharmaceutical Excipients. 5th ed. Washington DC and London: American Pharmacist Assiciation and Pharmaceutical Press; 2006.

2. Fengel D, Wegener G. Hardjono Sastroatmojo, Penerjemah. Kayu, Kimia, Ultrastruktur, Reaksi-reaksi. Yogyakarta:Gajah Mada Press; 1995

3. Fitriasari W, Hermiati E. Analisis morfologi serat dan sifat fisis-kimia pada enam jenis bambu sebagai bahan baku pulp dan kertas. Jurnal Ilmu dan Teknologi Hasil Hutan. 2008;1(2):67-72.
4. Koh May Hong. Preparation and Characterization of Carboxymethyl Cellulose From Sugarcane Bagasse. [Skripsi]. Malaysia: Universiti Tunku Abdul Rahman. 2013.

5. Kharismi RRAY, Sutriyo, Suryadi H. Preparation and Characterization of Microcrystalline Cellulose Produced from Betung Bamboo (Dendrocalamus asper) through Acid Hydrolysis. J Young Pharm. 2018;10(2):s79-83.

6. Suryadi H, Sutriyo, Sari HR, Rosikhoh, D. Preparation of microcrystalline cellulose from water hyacinth powder by enzymatic hydrolysis using cellulase of local isolate. J Young Pharm. 2017;9(1):s19-23

7. United States pharmacopeia conventions. United states pharmacopeia. 32th ed. United States: United States Pharmacopeia Conventions; 2008.

8. Coniwanti P, Dani M, Daulay ZS. Pembuatan Natrium Karboksimetil Selulosa (Na-CMC) dari Selulosa Limbah Kulit Kacang Tanah. Jurnal Teknik Kimia. 2015;4(21):57-64

9. British Pharmacopoiea. London: The Stationary Office; 2009.

10. Mann G, Kunze J, Loth F, Fink HP. Cellulose Ethers with a Blocklike Distribution of the Substituents by the Structure-selective Derivatization of Cellulose. Polymer. 1998; 39:3155-3165.

11. Majewicz TG, Ford C. Preparation of CMC with improved subtituent uniformity using borax. United States Patent; CA1171082A. 1981.

12. Saputra AH, Qadhayna L, Pitaloka AB. Synthesis and characterization of carboxymethyl cellulose (CMC) from water hyacinth using ethanol-isobutyl alcohol mixture as the solvents. Int J Chem Eng Appl. 2014;5(1):36-40.

13. Nikonenko NA, Buslov DK, Sushko NI, Zhbankov RG. Investigation of Stretching Vibrations of Glycosidic Linkages in Disaccharides and Polysaccarides with Use of IR Spectra Deconvolution. Biopolymers. 2000;57(4):257-62. 
14. Liu Y. Recent progress in fourier transform infrared (FTIR) spectroscopy study of compositional, structural and physical attributes of developmental cotton fibers. Materials (Basel). 2013;6(1):299-313.

15. Pecsok RL, Shields LD, Cairns T, McWilliam IG. Modern methods of chemical analysis. New York: John Wiley and Sons; 1976.
16. Oun AA, Rhim JW. Preparation and characterization of sodium carboxymethyl cellulose/cotton linter cellulose nanofibril composite films. Carbohydr Polym. 2015;127:101-9.

17. Mario PA, Djagal WM, Haryadi. Synthesis and s (Musa cavendishii LAMBERT). Carbohydr Polym. 2005;62:164-9.

Cite this article: Suryadi H, Sutriyo, Fauziah G. Characterization Sodium Carboxymethyl Cellulose from Alpha Cellulose Betung Bamboo (Dendrocalamus asper). Pharmacog J. 2019;11(5):894-900. 